\title{
Identification of the Thermal Constants of the DPL Heat Transfer Model of a Single Layer Porous Material
}

\author{
Maria Strąkowska, Bogusław Więcek \\ Lodz University of Technology, Institute of Electronics, Wólczańska 211/215, 90-924 Łódż, Poland \\ Gilbert De Mey \\ Ghent University, Faculty of Engineering, Technologiepark 125, 9052 Ghent-Zwijnaarde, Belgium
}

\begin{abstract}
This paper deals with parameters' identification of the Dual Phase Lag (DPL) thermal model of a 3D printed porous materials. The experiments were performed for two porous materials with different filling factors. The Laplace transform was applied for the heat transfer equation and together with different optimization methods it allowed to identify the thermal time constants of the DPL model. Several optimization methods were tested with known parameters in order to confirm the correctness of the parameters' estimation.
\end{abstract}

Keywords: DPL model, porous material, thermal time constants, IR thermovision, thermal conductivity

\subsection{DPL model of a porous material}

Let us consider a slab made of porous material with thickness $d$. Heating is generated at the bottom side by heat flux $q(d)$. In addition the convection cooling is applied at the upper surface where the temperature is measured by a thermographic camera, as shown in figure 1.

The solution of 1D Fourier-Kirchhoff differential equation $[1,2]$ in frequency domain for a sourceless object takes a form [3-5].

$$
T(x, j \omega)=A e^{-\frac{x}{L}}+B e^{\frac{x}{L}}
$$

where $A$ and $B$ are the integration constants.

The diffusion length $L(j \omega)$ varies with frequency and is defined as in equation (2).

$$
L(j \omega)=\sqrt{\frac{k}{j \omega C_{t h}}}
$$

where $k$ is thermal conductivity and $C_{t h}$ is volumetric thermal capacity.

\section{Autor korespondujący:}

Maria Strąkowska, maria.strakowska@p.lodz.pl

\section{Artykuł recenzowany}

nadesłany 31.05.2021 r., przyjęty do druku 28.06.2021 r.

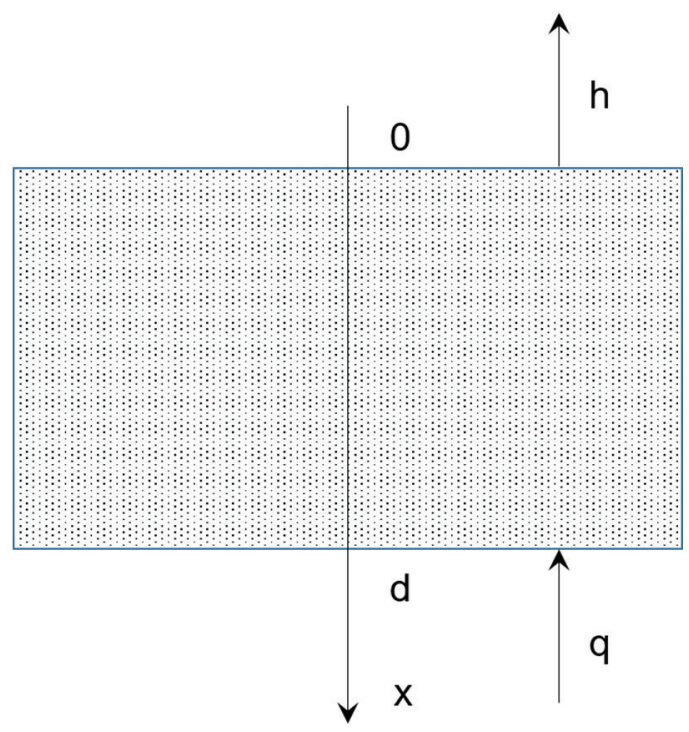

Fig. 1. The model geometry Rys. 1. Geometria modelu

The Dual Phase Lag (DPL) model assumes that the heat is transferred not only due to the temperature gradient. In addition, thermal energy can be generated and transfers if both the temperature and the heat flux are varying in time. In consequence, two additional time constants are introduced displaying both an additional relaxation of heat $\tau_{q}$ and a lag of temperature $\tau_{T}[3,6-8]$.

$$
q+\tau_{q} \frac{\partial q}{\partial t}=-k\left(\frac{\partial T}{\partial x}+\tau_{T} \frac{\partial^{2} T}{\partial x \partial t}\right)
$$


Using the Laplace transform for the equation (3) it is possible to redefine the heat flux and thermal conductivity in the more general forms [3]:

$$
q=-\widetilde{k} \frac{\partial T}{\partial x}
$$

where:

$$
\widetilde{k}=k \frac{1+s \tau_{T}}{1+s \tau_{q}}
$$

The DPL method developed in this research is based on equation (1) and (2) with redefined thermal conductivity expressed by the equation (5).

\section{The boundary conditions}

The porous sample has the thickness $d$ and is heating by the flux $q(x=d)$ at the bottom side.

$$
q=-\left.\widetilde{k} \frac{\partial T(x)}{\partial x}\right|_{x=d}
$$

At the upper surface the convection cooling with heat transfer coefficient $h$ is applied. It is assumed that the ambient temperature is equal to 0 .

$$
\left.\widetilde{k} \frac{\partial T(x)}{\partial x}\right|_{x=0}=h \cdot T_{x=0}
$$

\section{The solution of the model}

Using the above equations, it is possible to define the set of two linear equations that allow calculating the integration constants $A$ and $B$.

The integration constants take the forms:

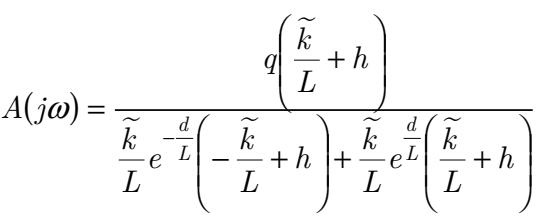

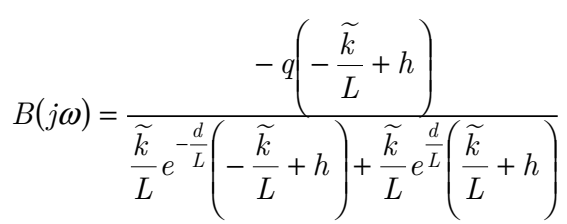

Analytical solution of the heat transfer model (1) for $x=0$ and $x=d$ leads to determine both values of temperature in frequency domain.

$$
\begin{gathered}
T(x=0, j \omega)=A+B \\
T(x=d, j \omega)=A e^{-\frac{d}{L}}+B e^{\frac{d}{L}}
\end{gathered}
$$

The temperature and power of heating the sample from below, both defined in the frequency domain, allow to determine the thermal impedance $Z_{t h}(j \omega)$ of an object (10). This is so-called transfer thermal impedance.

$$
Z_{t h}(j \omega)=\frac{T(j \omega)}{P(j \omega)}
$$

Typically, power is the Heaviside step function represented in frequency domain as $P(j \omega)=P_{0} / j \omega$.

\section{Experimental setup}

The experiments were performed by heating up a porous material slabs by an electronic circuit with a power transistor (fig. 2).

The slab was thermally connected to the transistor using the thermal grease. The porous material slabs with different filling factors were fabricated using the $3 \mathrm{D}$ printer. Two values of filling factors $57 \%$ and $76 \%$ were chosen the experiments. The size of the cuboid samples made of the porous material was $12 \mathrm{~mm}$ $\times 7 \mathrm{~mm} \times 5 \mathrm{~mm}$. The constant power of $P_{0}=0.3 \mathrm{~W}$ dissipated in the transistor was selected. Such power can increase temperature of the upper surface of porous material by about $30 \mathrm{~K}$ within a few minutes.

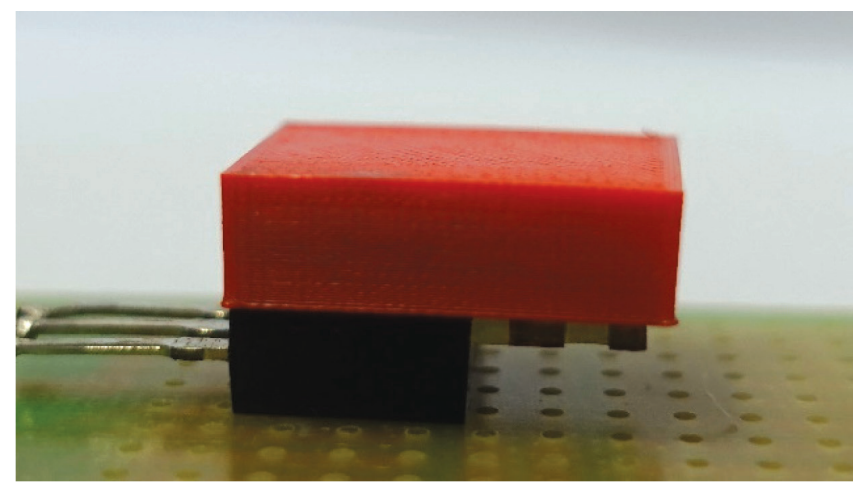

Fig. 2. The porous material on the heat source

Rys.2. Materiał porowaty na źródle ciepła

a)

b)

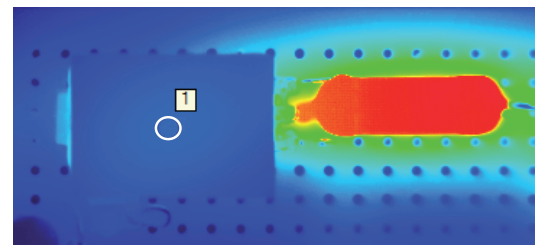

Fig. 3. Experiment: a) one of the registered thermal image of a porous material during heating up, b) measurement setup - MWIR camera above the sample during registration of thermal images

Rys. 3. Eksperyment: a) obraz termowizyjny materiału porowatego zarejestrowany podczas grzania, b) stanowisko pomiarowe - kamera MWIR umieszczona nad badaną próbką podczas rejestracji sekwencji termogramów

The cooled thermal camera MWIR Cedip Titanium registered the sequence of thermal images during heating the samples. The camera frame rate $100 \mathrm{~Hz}$ was selected and the images were registered during more than $800 \mathrm{~s}$. Then, temperature evaluation in time was extracted from the marked region of interest as it is shown in figure 3 .

\section{Identification of thermal time constants in the DPL model of a porous material}

Model parameters identification procedure consisted in matching the thermal impedance from the measurement and the 
DPL model. In order to perform such matching, the different optimization algorithms were applied. After temperature measurement by a thermal camera, the smoothing of the signal by the Kalman Filter was performed. Then, temperature signal was transform from time to frequency domain using the Laplace transform with Filon integration. As a result, the measured thermal impedance was estimated and presented as the Nyquist plot. On the other hand, the analytical thermal model developed in frequency domain allowed to obtain the thermal impedance directly. The final step in identifying thermal time constants is optimization, which leads to changing the model parameters according the matching error between thermal impedances from the model and the measurement.

In order to verify the correctness of the proposed approach of identifying thermal time constants, temperature curves during heating the samples were artificially generated using the DPL thermal simulations with arbitrary chosen thermal parameters of a porous materials. Three models with different values of thermal parameters including DPL thermal time constants were defined as shown in table 1. As a result, thermal impedances and step-function temperature responses were generated to be compared during the inverse modelling. Various optimization algorithms with different initial values of thermal parameters including thermal time constants were selected as shown in table 2 .
Five optimization methods were tested on three DPL models in the MATLAB environment - patternsearch, paretosearch, multiple-objective genetic, fmincon and twiddle algorithms and runs on Intel core i7 8th Gen 2.2-4.1 GHz (i7-8750h). The patternsearch optimization method is a numerical approach also called as direct search method and it finds the solution around the existing points. When the solution is not found, expansion or contractions around current points take place. The patternsearch method does not rely on gradients and it is derivative-free [9]. It is recommended for noisy measurements and simulations of ill-conditioned problems that need the very small parameter change with high-resolution numeric representation of data. Unfortunately, thermal problems are belonging to such cases. The paretosearch algorithm also applies pattern search approach on a set of points to find a solution iteratively for non-dominated points [10]. In this research, a genetic optimization was also used for verifying both accuracy, complexity and execution time of the algorithm. Widely used in other applications multiple-objective genetic algorithm was chosen [12]. The fmincon algorithm is a gradient methods used for nonlinear fitting problems for many technical applications as it guarantees accuracy and effectiveness [11]. The last twiddle optimization method is a very simple, an intuitive algorithm consisting in changing the values of the model parameters up and down, while carefully following the objective function.

Table 1. Parameters of the model tested by different optimization algorithm

Tabela 1. Parametry modelu wykorzystane do testowania różnych algorytmów optymalizacji

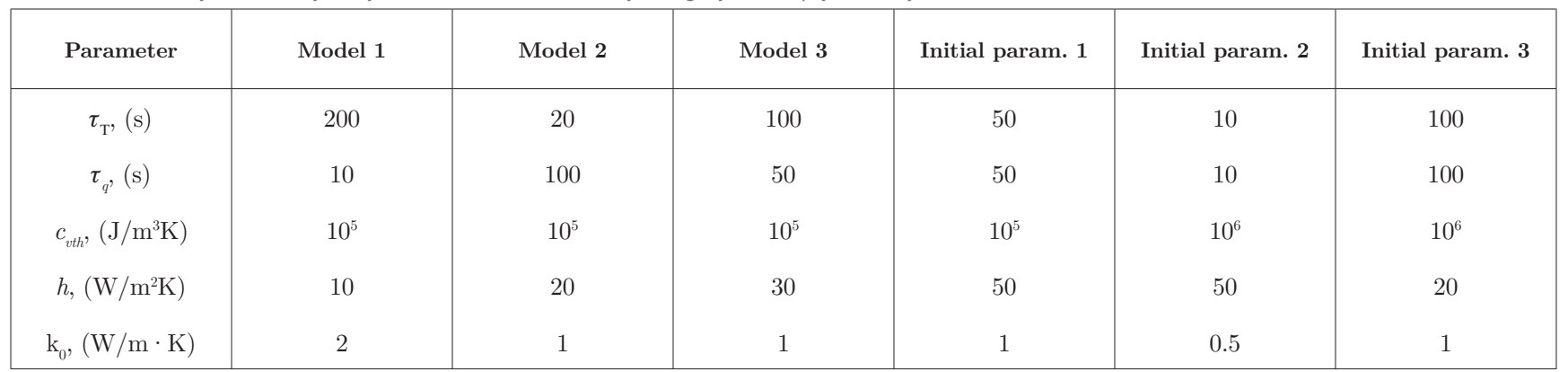

Table 2. Thermal impedance matching errors and execution time for various optimization algorithms Tabela 2. Błędy dopasowania impedancji termicznej oraz czas działania różnych algorytmów optymalizacji

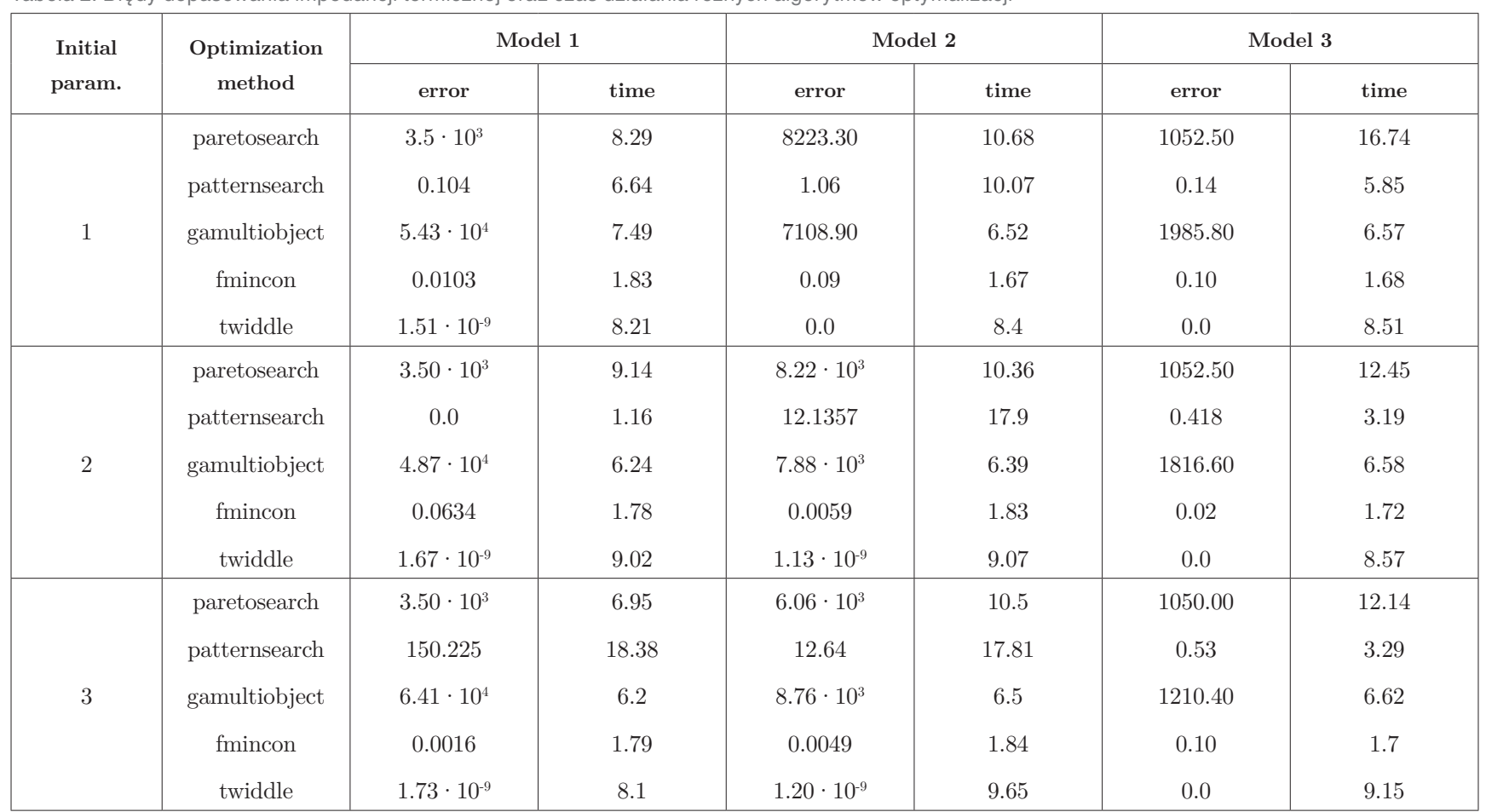


a)

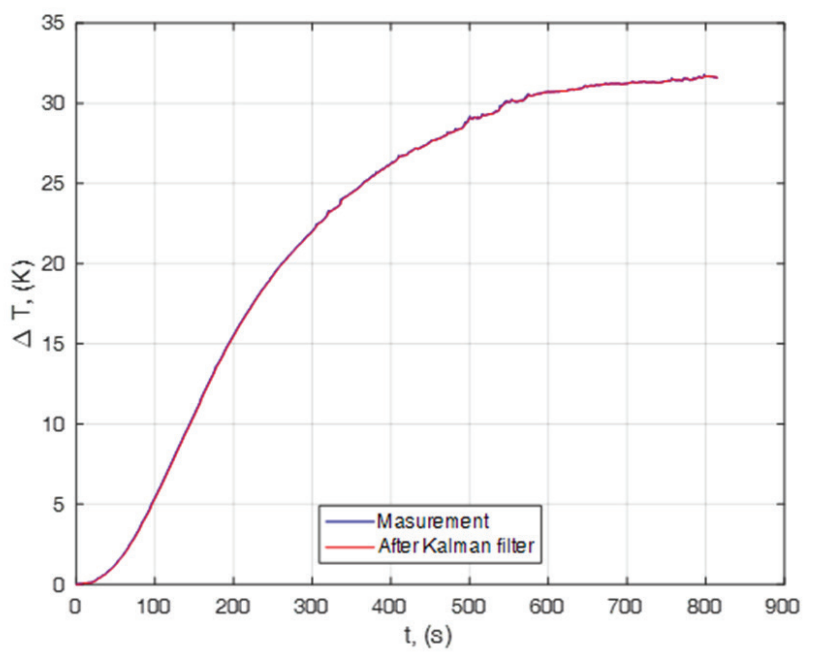

b)

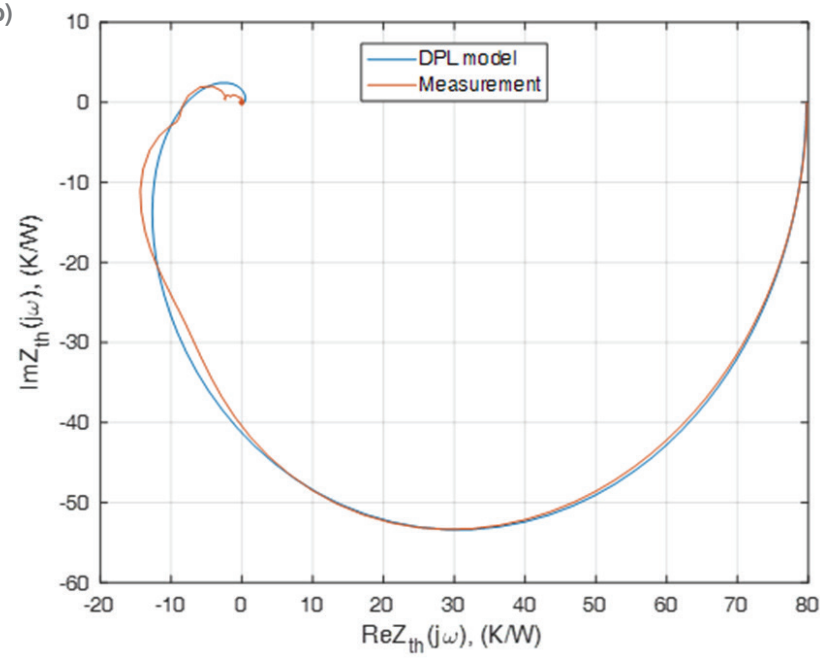

Fig. 4. Results for the porous sample with $57 \%$ fill factor, a) measured temperature, b) measured and fitted transfer thermal impedance

Rys. 4. Wyniki dla materiału porowatego o współczynniku wypełnienia $57 \%$, a) pomiar temperatury, b) impedancja termiczna uzyskana z pomiaru i po dopasowaniu

The results of optimization for synthetic data are presented in table 2. As one can see the twiddle algorithm gives the best results for all simulated cases with different starting points of optimization. In consequence, the twiddle algorithm was chosen for further research.

The final step of this research refers to the thermal time constants identification of a real porous material heated up on the bottom side by a transistor and temperature measurement on the upper side by a thermographic camera (fig. 3).

Two porous materials were tested during the experiments, the first with $57 \%$ and the second with $76 \%$ filling factors. Figures 4a) and 6a) show the temperature evaluation in time registered by the photon cooled thermal camera with $100 \mathrm{~Hz}$ frame rate. The figures show the raw and the denoised temperature curves using the scalar Kalman filter.

As the measurement side is far away from the heat source, the transient thermal impedance is calculated. The figures $4 \mathrm{~b}$ ) and $6 \mathrm{~b}$ ) show the transient thermal impedances obtained both from the measurements and with the use of the proposed thermal model after fitting to the twiddle algorithm.

Figures 5 and 7 present recovered temperature evolution versus time using Frequency domain Thermal Object Identification (FredTOI) methodology. It is based on the Vector Fitting and the Laplace transform with correction for high-frequency range [4].

Table 3 contains the recovered thermal parameters for two porous material samples using the inverse thermal modelling

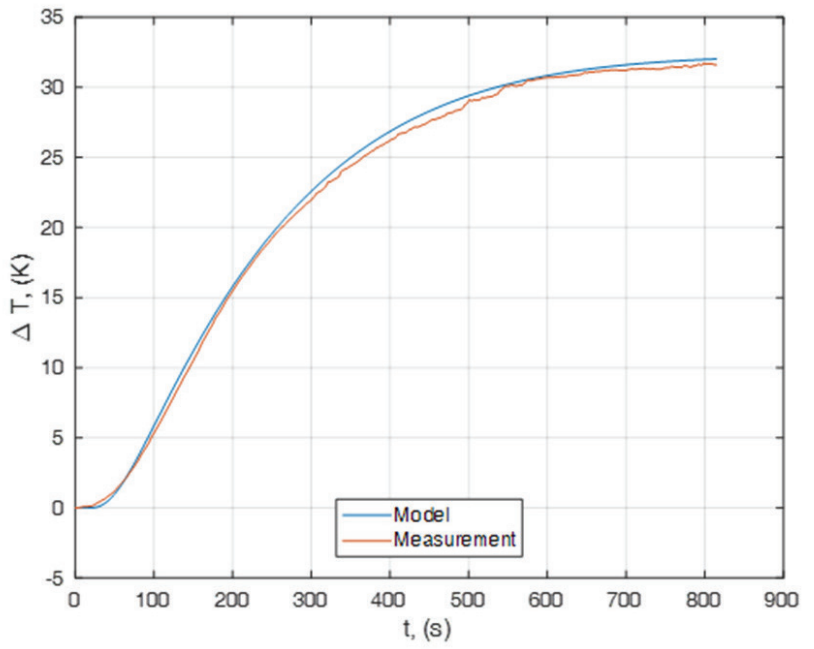

b)

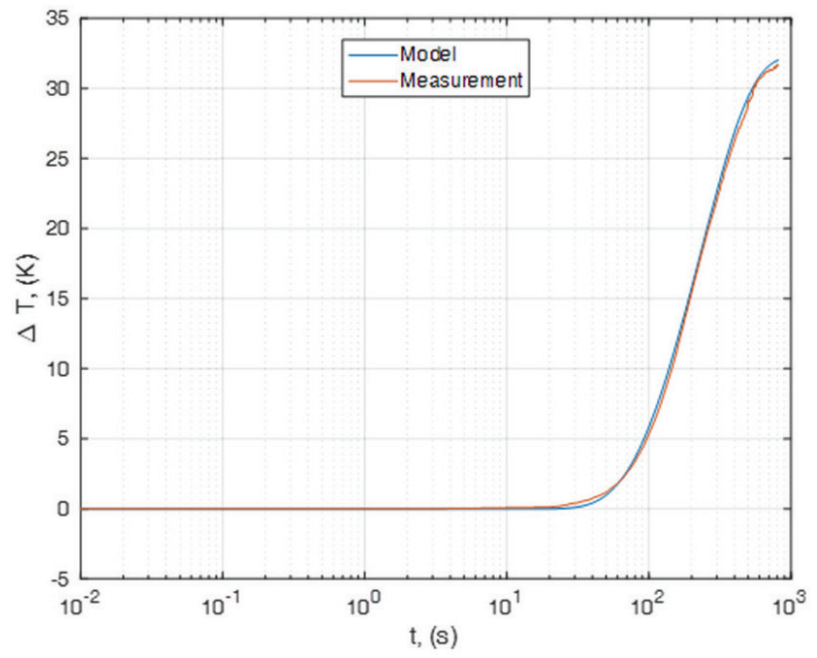

Fig. 5. Measured and fitted simulated temperature for a porous sample with $57 \%$ fill factor

Rys. 5. Temperatura materiału porowatego o wypełnieniu $57 \%$ uzyskana z pomiaru i z modelu

in frequency domain developed in this research. Among them, there are thermal time constants of non-Fourier DPL model of heat transfer in porous materials.

It can be seen that that the relaxation thermal time constant $\tau_{q}$ is larger than inertial one $\tau_{T}$. It is not a typical relation found in literature. It needs the further studying for physical and theoretical explanation. The rest of the identified parameters of porous material seem to have the expected values according to the fill factor.

\section{Conclusions}

Identification of thermal constants of the DPL heat transfer model was done by analyzing temperature measurement in frequency domain and optimization of the parameters of the thermal model. Few optimization methods were tested on artificial generated model with known parameters in order to confirm the correctness of estimated parameters in real measurement. All considered methods are sensitive to initial conditions, except for the gamultiobject method which finds the result within the given parameter range. However, this method is not sufficiently convergent for the conducted research, and therefore it was rejected for further consideration. The same conclusion is valid for the paretosearch method. The differences in optimization and modelling results for these methods are too large to be used in real material measurements. Run time 
a)

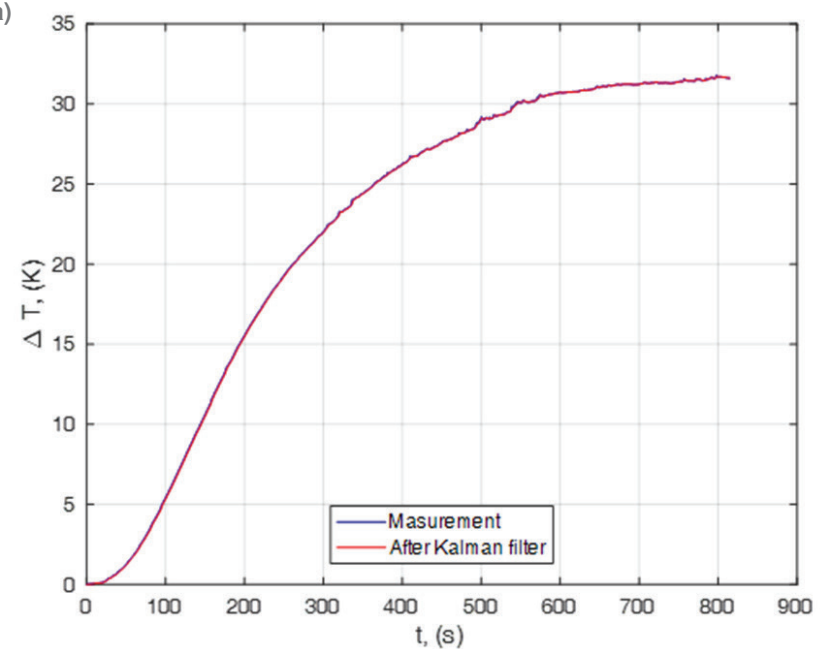

b)

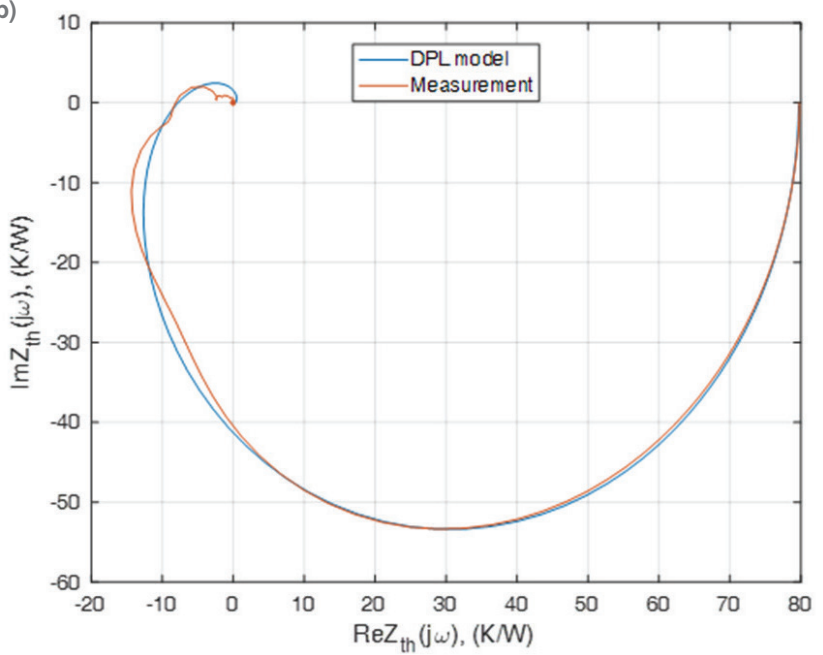

Fig. 6. Results for the porous sample with $76 \%$ fill factor, a) measured temperature, b) measured and fitted transfer thermal impedance

Rys. 6. Wyniki dla materiału porowatego o współczynniku wypełnienia $76 \%$, a) pomiar temperatury, b) impedancja termiczna uzyskana z pomiaru i po dopasowaniu

was different for the considered methods of optimization. The smallest one was reached for fmincon method. For the patternsearch the run time depends on the complexity of the problem. The Twiddle method is run for a given number of iterations, so its execution time for each of the presented example is almost the same. The number of iterations was more than enough to correctly solve the real measurement problem. Due to the fact that the average error is the smallest for the Twiddle method, this algorithm was chosen to optimize for the real material measurement. The obtained results for the measurements of the porous materials with different filling factors are satisfactory. The estimated parameter values are as expected. Only the relation between the values of the time constants $\tau_{q}$ and $\tau_{T}$ seems to be opposite when compared to the data from the literature. This relationship will be tested on various materi-

Table 3. Model parameter values adjusted to the experimental data Tabela 3. Parametry modelu dopasowanego do danych eksperymentalnych

\begin{tabular}{|c|c|c|}
\hline Parameter & $\mathbf{5 7} \boldsymbol{\%}$ fill factor & $\mathbf{7 6} \boldsymbol{\%}$ fill factor \\
\hline Thermal conductivity $k,(\mathrm{~W} / \mathrm{m} \cdot \mathrm{K})$ & 0.034 & 0.049 \\
Thermal capacity $c_{v t h},\left(\mathrm{~J} / \mathrm{m}^{3} \mathrm{~K}\right)$ & 165515.3 & 232615.5 \\
Relaxation time constant $\tau_{q},(\mathrm{~s})$ & 241.74 & 186.25 \\
Inertial time constant $\tau_{T},(\mathrm{~s})$ & 213.64 & 148.78 \\
\hline
\end{tabular}

a)

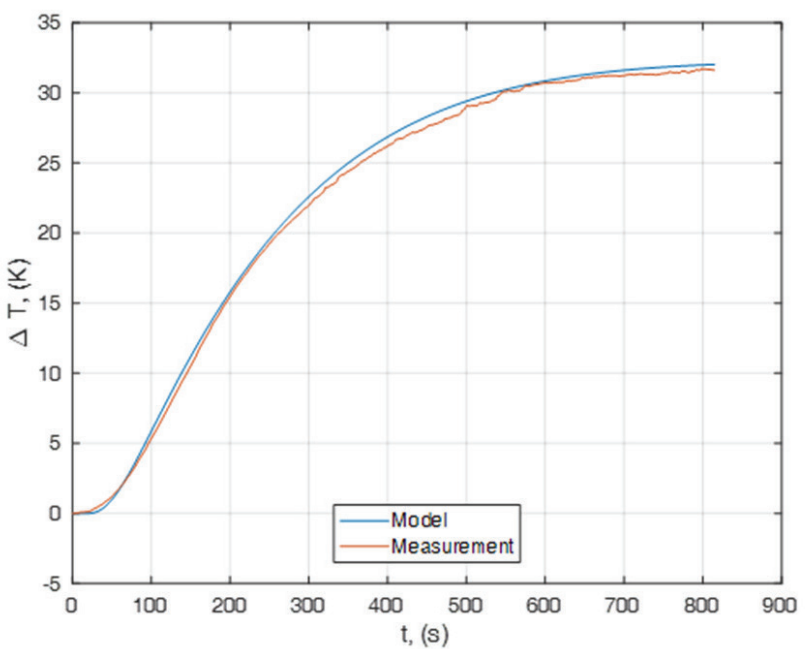

b)

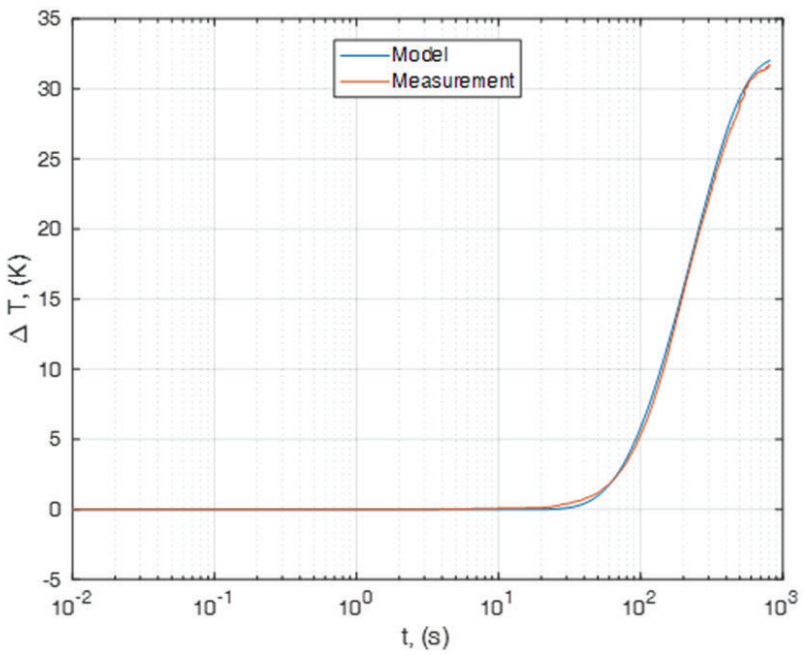

Fig. 7. Measured and fitted simulated temperature for a porous sample with $76 \%$ fill factor

Rys. 7. Temperatura materiału porowatego o wypełnieniu $76 \%$ uzyskana z pomiaru i z modelu

als in further research. Subsequent measurements will also be carried out for the DPL-affected skin tissue.

\section{References}

1. Bejan A., Heat transfer. Wiley, New York, 1993.

2. Incropera F., De Witt D., Introduction to heat transfer. Wiley, New York, 1985.

3. Strąkowska M., De Mey G., Więcek B., Comparison of the Fourier-Kirchhoff, Pennes and DPL thermal models of a single layer tissue, [In:] $15^{\text {th }}$ Quantitative InfraRed Thermography Conference, 21-30 September 2020, Porto (Portugal), DOI: $10.21611 /$ qirt.2020.127.

4. Strąkowska M., Chatzipanagiotou P., De Mey G., Więcek B., Multilayer thermal object identification in frequency domain using IR thermography and vector fitting, "International Journal of Circuit Theory And Applications", Vol. 48, No. 9, 2020, 1523-1533, DOI: 10.1002/cta.2845.

5. Strąkowska M., Chatzipanagiotou P., De Mey G., Chatziathanasiou V., Więcek B., Novel software for medical and technical Thermal Object Identification (TOI) using dynamic temperature measurements by fast IR cameras, [In:] 14 ${ }^{\text {th }}$ Quantitative InfraRed Thermography Conference, QIRT 2018, June 25-29, 2018, Berlin, DOI: 10.21611/qirt.2018.053, http://qirt.gel.ulaval.ca/archives/qirt2018/papers/053.pdf.

6. Tzou D.Y., Macro-to Microscale Heat Transfer: The Lagging Behavior, 2nd ed., Wiley, 2014, ISBN: 978-1-118-81822-0. 
7. Zubert M., Raszkowski T., Samson A., Zając P., Methodology of determining the applicability range of the DPL model to heat transfer in modern integrated circuits comprised of FinFETs, "Microelectronics Reliability", Vol. 91, 2018, 139-153, DOI: 10.1016/j.microrel.2018.07.141.

8. Ciesielski M., Mochnacki B., Majchrzak E., Integro-differential form of the first-order dual phase lag heat transfer equation and its numerical solution using the Control Volume Method, "Archives of Mechanics", Vol. 72, No. 5, 2020, 415-444, DOI: 10.24423/aom.3555.
9. Audet Ch., Dennis J.E. Jr., Analysis of Generalized Pattern Searches, "SIAM Journal on Optimization", Vol. 13, No. 3, 2003, 889-903, DOI: 10.1137/S1052623400378742.

10. Custòdio A.L., Madeira J.F.A., Vaz A.I.F., Vicente L.N., Direct Multisearch for Multiobjective Optimization, "SIAM Journal on Optimization", Vol. 21, No. 3, 2011, 1109-1140, DOI: $10.1137 / 10079731 \mathrm{X}$.

11. [www.mathworks.com/help/optim/ug/nonlinear-constraints-with-gradients.html]

12. Deb K., Multi-Objective Optimization using Evolutionary Algorithms, John Wiley \& Sons, Inc., 2001.

Streszczenie: Artykuł przedstawia nową metodę identyfikacji parametrów termicznych modelu Dual Phase Lag (DPL) materiałów porowatych drukowanych na drukarce 3D. Eksperymenty przeprowadzono dla dwóch materiałów porowatych o różnych współczynnikach wypełnienia. Do rozwiązania równań przepływu ciepła zastosowano transformację Laplaca, a następnie wykonano optymalizację w celu wyznaczenia wartości parametrów modelu w celu dopasowania ich do eksperymentu. Umożliwiło to identyfikację cieplnych stałych czasowych modelu DPL. Przetestowano również różne metody optymalizacji dla znanych wartości parametrów modelu w celu potwierdzenia poprawności identyfikacji.

Słowa kluczowe: model DPL, materiał porowaty, termiczne stałe czasowe, termowizja w podczerwieni, przewodność cieplna

\section{Maria Strąkowska, PhD Eng}

maria.strakowska@p.lodz.pl

ORCID: 0000-0001-6246-0086

Maria Strąkowska received the MSc degree in electronics in 2010 and the PhD degree in computer science in 2017, both from the Lodz University of Technology (LUT). From 2017 she is employee of the Institute of Electronics LUT as the Assistant Professor. Her scientific interests are focused on computer modelling of heat transfer phenomena in medicine and in electronics. Her fields of interest are also thermal image processing and thermography measurements.

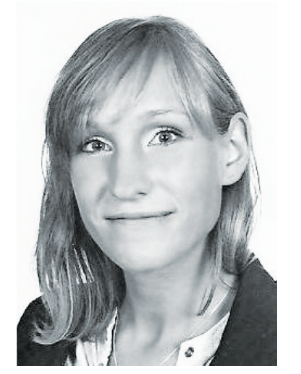

Prof. Gilbert De Mey, PhD

Gilbert.DeMey@UGent.be ORCID: 0000-0001-6083-8380

Gilbert De Mey was graduated at University of Chent, where he is working as a full professor. He conducts research on thermal problems in electronic systems. His main area of research concerns the issues of heat transfer in electronic components and systems using IR thermography as a tool for validation. It includes theoretical modelling and studies on heat transfer by convection and radiation.

\section{Prof. Bogusław Więcek, PhD DSc}

boguslaw.wiecek@p.lodz.pl ORCID: 0000-0002-5003-1687

Bogusław Więcek is the head of Electronic Circuit and Thermography Division in the Institute of Electronics where he has been working for more than 40 years. His scientific interests are: heat transfer modelling, industrial and biomedical applications of IR thermography and IR system modelling and developments. He is responsible

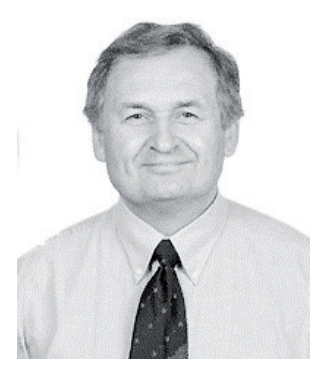

for organizing the largest conference on thermography in Central and Easter Europe every two years "Infrared thermography and thermometry - TTP". 